\title{
International Aspect of the Domestic (Family) Violence - Victims and Consequences
}

\author{
Afrim Osmani \\ State University of Tetova - Faculty of law, \\ Skopje-Macedonia \\ afrim2002@yahoo.com
}

\author{
Doi:10.5901/ajis.2014.v3n2p25
}

\section{Abstract}

Domestic violence is a kind of crime of violence which has always existed in human society. It is treated as a private matter within the family and as such is not treated by the state. There are adopted a number of Conventions and other international acts banning family violence. Such actions are incriminated in the national laws, there are created institutions of various international and national bodies combating this phenomenon, all this in order of awareness of human society that family violence is not a private matter but a matter that touch all and should be treated the same by the state as other forms of violence, regardless of its private nature. Within the state are also created various non-governmental organizations, to protect victims of family violence, whose address this issue and try preventively to influence to the society to eliminate or mitigate the consequences of the family violence. Domestic violence as a phenomenon and as a form of criminality was written a lot, in international as well as national levels. Many researchers have written about the reasons for submission, submission forms, preventive policy of the state, for the criminal incrimination of the family violence and so on. We as a society, should focus more on the protection of victims, on the proper treatment of their institutional, legal, all this in order to soften a little bit their pain, help in rehabilitation, socialization and to provide the conditions for a better life and different from what they have had so far. If the state offers adequate protection and assistance to victims of family violence, there is no doubt that it will affect to denunciation of the violence in the authorities and in this way to influence in reduction of the unknown number of this offense, which no doubt is very large. In cases of domestic violence, where the victims are mostly weaker persons, women, children, disabled parents, not enough awareness for presenting the case or conviction of the perpetrator, it is necessary that adequate care to victims, their treatment institutional aid, protection from the perpetrator and so on, because the victims in most of the cases do not report family violence or tolerate it because of the dependency that the abuser and fear that if violence would pose difficulties in essential to continued life. Therefore, victims should be proven that there is one who cares for them and provides sufficient protection and conditions for the rest of their life, without violence, without fear, in a harmony and family welfare, just as does a healthy family functioning. So, domestic violence should scrutiny from international aspect, including here the entire legal act approved by international community. Aim of this paper is to find out how through international measures is fighting this phenomenon in the society.

Keywords: domestic violence, victims, international acts, consequences, prevention and inhibition.

\section{Definition of the Family Violence}

Domestic violence is a phenomenon that occurs in every society, in every state and represents one of the most brutal violations of basic human rights. This form of violence appears exactly where the individual should feel very safe, where to live quiet and at ease, so the family home.

Domestic violence has always existed. However, if we compare the cases of family violence in the past and today, we have the impression that today there are more cases of family violence. This impression is due for submission awareness of victims of this form of violence to the authorities, so it's evidencing and toleration of the same, rather than increased its number. This form of violence is not treated properly because it happened within the walls of the house, the family, and is often regarded as a private matter. But over time this concept has begun to change though perhaps not to the extent now satisfactory and tango this form of violence throughout society, not just family. Until this change came after the society awareness of the rights and fundamental freedoms, equal treatment of all people regardless of gender, age, race, religion etc. When these rights were proclaimed and when was banned any form of family violence in the family then began to be treated as a general matter and began to take measures to prevent and combat it.

Criminal Codes of different countries define family violence: "With family violence meant ill, rude insult, threat security, bodily injury, gender violence or other psychological or physical violence which causes the feeling of insecurity, threat or fear, to the husband / wife, parents or children or other persons living in marital or extra-marital or common 
community, and to the husband/wife-with previous or other persons who have a child in common or are in close relationships personal.

Family laws and other laws also define family violence as maltreatment, slander, breach of security, bodily injury, other psychological or physical violence based on gender which causes the feeling of insecurity, danger or fear among family members. Family violence involves the combination of power and control that used to cause pain and fear to the victim, in order to keep control over it, be humbled and overwhelmed. Family violence is a behavior whereby an intimate partner or family member more extensive uses physical violence, coercion, intimidation, isolation or emotional abuse, sexual or economic abuse to control the partner / other family member in the relationship / household.

The issues of family violence against women are addressed in the Convention and various international resolutions from the legislature early but never explicitly. Family violence is defined as violence against women, given the fact that the majority of victims are women. Changes in this regard we have adopted international documents recent years, which explicitly define the notion citing family violence.

Article 1 of the UN Declaration on the elimination of violence against women states: "The term violence against women means any act of gender-based violence that results in, or there is confidence that will result in, physical, sexual or psychological causes as well as incurrence of women, including threats such acts, coercion or arbitrary deprivations of liberty, whether occurring in public or in private life" (UN Declaration on the Elimination of Violence against Women, adopted by General Assembly resolution A/RES/48/104, 20.12.1993.).

Beijing Declaration and Platform for Action adopted in 1995 at the Fourth Conference of Women in Beijing, devotes a whole issue of violence against women, including violence perpetrated within the family. In part D, section 113 - a defined family violence where the previous definition given in the Declaration on the elimination of family violence also added "... In accordance with this, violence against women encompasses but is not limited only to: In line with this, violence against women encompasses but is not limited only to:

a) Physical, sexual and psychological violence occurring in the family, including battering, sexual abuse of female children in the household, marital rape, female genital mutilation and other traditional practices that are harmful to women, non-spousal violence and violence concerns to use (Beijing Declaration and Platform for Action, Fourth World Conference on Women, Beijing, September 1995, http://www.un.org/womenwatch/daw/beijing/platform/index.html).

Convention on preventing and combating violence against women and family violence, the Council of Europe adopted in 2011, uses the term family violence and defines it as all acts of physical, sexual, psychological or economic that occur within the family or household or between partners or former or current spouses, regardless of the perpetrator shares or has shared the same residence with the victim (Convention on preventing and combating violence against women and domestic violence, the Council of Europe - CAHVIO, 12.04.2011, Article 3, paragraph b.).

\section{Victims and Consequences of the Family Violence}

As a result of family violence, there is causing victims and many other serious consequences. Victim of family violence can be any family member, regardless of gender or age. But in most cases of family violence victims are presented as women and children.

As domestic violence is considering behavior conducted:

- From one spouse to the other spouse who live or have lived in marital or extramarital or in any other community, as a family or who have children in common;

- Between brothers and sisters, half brothers and sisters;

- The child;

- To the older members of the family;

- Persons - family member whose working ability partially or completely been taken.

According to this, as a victim of family violence may appear:

- Women as victims of family violence;

- Children as victims of family violence;

- Elderly parents and disabled victims of family violence and

- Men as victims of family violence.

\subsection{Women as victims of family violence}

The largest number of victims of family violence belongs to women. This finding gives as literature that deals with this 
issue as well as various statistics states. In many cases family violence often identified with the term violence against women (woman). Women experience violence of all cultures, ethnicities, religions. Although in most cases of family violence, victims come from lower strata of society and education are low, this does not exclude the fact that reports of family violence by women with no higher education and social status raise.

Unfortunately women are experiencing violence where they should feel safest, in the family. Her abuser in most cases is the person who normally must be her life partner, her protector, and her children's father. Right here lays the problem of this kind of violence, even in certain relations victim - perpetrator. These relationships in the society especially in more developed societies not considered private, as family issues that cannot or should not be treated by others. Therefore the number of dark this crime is very high. There are women who represent the violence and seek help. But a large number of beautiful women prefer to endure more intimate partner violence than to seek help for the same. Even there are cases when violence from spouse is treated as "normal" by the victims.

Reasons for not reporting violence victims are the most varied: ignorance of their rights, fear of the abuser, fear of family shame circle, economic dependence on the husband - respondent, confidence in the authorities that the same can help, for the sake of the children (which unfortunately are not aware that family violence affects the welfare of children, even in the formation of their personality, a child who grows up in an environment where family violence has major prerequisites when it applies also increase violence, etc.).

According to the results of studies on victims, it appears that women, who are victims of violence in marriage and the family, usually have some features that are more or less identical. Usually it comes to women, women who live in problematic marriages, where there are contradictions and disagreements between spouses, between parents and children, between family members, so are women or women who suffer from various diseases, are pregnant, are before divorce, are widows, are women who live in reports and informal links or out of wedlock, are the only family nutritious, are women in their lives from early childhood trauma suffered stress, have also been previously victimized, abused females in the family environment, women are unemployed or engaged in suspicious activity and illegal trafficking etc (Halili, Prishtinë, 2007, p. 75-76.).

The violence against women within the family is all kinds. Starting from psychological violence, emotional, physical, sexual and even in some cases even violence that epilogue death, whether the firearm or other deadly. In addition to these forms that violence can manifest with some other forms, such as food restriction, limitation of freedom of movement, restriction of health care, the economic and financial tools, as well as other forms of violence.

According to the victimology literature, the properties of women, female gender, often considered indeterminate victimogy properties. The women are more than men exposed to risk of victimization in life. Explanations of the reasons and factors affecting its victimization more frequently are different. These explanations rely mostly on highlighting the characteristics and impacts of natural biological, psychological and social (Halili, Prishtinë, 2007, p. 73).

\subsection{Children as victims of family violence}

When is talking about family violence, especially violence against children, we should note that here we are dealing with a very sensitive categories of victims. Especially their sensitivity comes as a result of their age (immaturity) and juvenile inability to protect others. The child safety at school or at home should provide parents. So the child protective umbrellas are parents.

Childhood medical disciplines, psychological and pedagogical considered a crucial period for the future development of the children as individuals and as citizens. The importance of this period for all further development makes it necessary for children to show special care for them to meet those developmental needs. One of them is the need for certainty and without the fulfillment of this need is impossible to have healthy individuals and responsible citizens. Violence against children in our society often applied as educational measure and as a rebuke for making action. Beating the child, as a method of discipline, achieved far more negatives than positives, because children can take aggression as behavior pattern (Violence against children in Albania, Human Development Centre, the research report funded by UNICEF, Author: Adem Tamo, Karaj, Tirana, 2006).

Many children were subjected to harsh and degrading forms of violence and humiliation as beating, incest, sexual abuse, abandonment, sale and use of children for prostitution, crimes of honor, to the selective abortions. Recent years have increasingly reported cases of sexual abuse by parents, teachers and others on children as well as deaths due to violence (Violence against children in Albania, Human Development Centre, the research report funded by UNICEF, Author: Adem Tamo, Karaj, Tirana, 2006).

Protection of children from violence in the family and even the definition of such violence also proclaim Convention 
on the Rights of the Child. It states in Article 19 obliges signatories "shall undertake all appropriate legislative, administrative, social and educational measures to protect children from all forms of physical or mental violence, injury or abuse, negligent treatment, maltreatment or exploitation, including sexual abuse, either while under the care of parent / s, guardian or other person who should care for the child (Convention on the Rights of the Child, General Assembly Resolution UN 44/25, 11/20/1989).

Violence is usually hidden. Children are not able to report acts of violence due to fear of violence. Maybe both, both the child and the abuser not see anything unusual or wrong to the child is the subject of violence. They probably do not consider that an act of family violence is actually, probably see it as a reasonable punishment and deserved. This often makes the child not want to talk about it (violence) (http://www.unicef.org/protection/index_violence.html, vizituar më: 18.08.2011).

\subsection{Elderly parents and disabled victims of family violence}

Victims of violence within the family may also be elderly parents and disabled who are under the care of their adult children. Here we are dealing with parents who experience various forms of violence by children who live, their spouses, children, nephews / nieces. The violence consists in not providing the necessary support and care of necessary, as may be not providing food, not meeting the basic conditions for prosperity at home, psychic ill with offensive words while aggravating escalated to physical violence cases.

In the constitutions of many countries children are obliged to pay particular attention to his parents by giving them the necessary assistance.

\subsection{Men as victims of family violence}

In a developing country, in a predominantly patriarchal society, in a country where the number of women and child victims of family violence is very high and still not achieve the required level of awareness of denunciation, especially for essential protection the most vulnerable victims (women and children), it is very difficult to talk about this category of victims of family violence. Usually, men in the highest number are perpetrators of family violence.

But this problem is not common in developed countries of the world. As cases also is existing men as victims of family violence, will also treat this category mainly based on data and knowledge from other countries. It is also evident that violence against men within the family there. There are many reasons why we do not know much about violence against men. The main factor is the failure or very rare appearance of this item and denunciation of family violence. For many, it is done and done so much to encourage and support women to report family violence, while for men it is not done and not done almost anything. The idea that man can be a victim of family violence is so unconceivable that neither male tend to present situation. Dynamics of family violence is different between men and women. The reasons, goals and motivations are often very different between the two sexes. To understand the issue of family violence against men is much less researched. In most cases it is said that the impact of family violence when the victim is male seen little or no circle than when the victim is female. For example, if a man has a sign in the eye, everyone thinks that he is hurt doing sports, it is beaten by any man or that has suffered accident. Even if they report violence, most people are surprised that so many men end up thinking that nobody believes. There are no absolute rules for understanding the emotional differences between men and women. Family violence against men and women has some similarities but also differences. As for both women and men in family violence includes pushing, kick, kick items, use of weapons, etc. On the other hand, what hurts men mentally and emotionally in some cases can be very different from what hurts a woman. For some men, their denomination words coward, impotent or failure can have psychological impact far greater than in females. Harsh words and hurt bad, but they can hurt and affect in different ways. In most cases, men are more exposed to violence than her physical psychic (Domestic Violence against men, 2007, http://www.oregoncounseling.org /Handouts/DomesticViolenceMen.htm).

According to a survey conducted in Great Britain, two of the five victims of family violence are men, contradicting the widespread impression so that they are almost always women who experience family violence. Data from the Home Office statistical bulletin shows that the UK men make up about $40 \%$ of victims of family violence between the years 2004-2005 and 2008-2009 (The Guardian, September 7, 2010, http://www.guardian.co.uk/society/2010/sep/05/menvictims-domestic-violence). 


\section{International Aspect of the Family Violence}

Acknowledgment that family violence brutal violation of human rights and fundamental freedoms in the international domain has sought a job during various activists, institutions and other bodies dealing with the issue of violence against women and family violence. International mechanisms for protecting victims of family violence occur in major international organizations such as the United Nations, the Council of Europe and the European Union. Today, all international legal instruments clearly stipulate that states have a duty to prevent and combat family violence.

As the largest reach in this regard is considered Declaration of Human Rights (10 December 1948) which serves as the reference basis for the adoption of resolutions, conventions and other human rights, especially for preventing violence and violence against women. "All human beings are born free and equal in dignity and rights and everyone is entitled to all the rights and freedoms enshrined in the Declaration, without distinction as to race, color, religion, thought (belief) political, national or social origin, property, birth or other status"( Universal Declaration of Human Rights, the General Assembly of the UN, 1948, Article 1 and 2).

\subsection{UN and women's rights}

UN support for women's rights began with the founding Charter of the Organization. Article 1 of the Charter states: "To achieve international cooperation in solving international problems of economic, social, cultural or humanitarian character and in promoting and encouraging respect for human rights and for fundamental freedoms for all without distinction of race, sex, language or religion" (UN Charter, 1945, which can be obtained at: http://www.un.org/en/documents /charter/intro.shtml).

Among the achievements of the Economic and Social Council, which established the Commission on the Status of Women, was to provide gender-neutral language in the draft of the Universal Declaration of Human Rights. International feminist movement began to gain importance during the 1970s, the General Assembly declared 1975 as the International Year of Women, and organized the first World Conference on Women, held in Mexico. At the request of the Conference later declared the years 1976-1985 as the UN Decade for women and established a Voluntary Fund for the Decade (http://www.un.org/en/globalissues/women/).

In 1979, the General Assembly adopted the Convention on the Elimination of All Forms of Discrimination against Women (CEDAW), which is often described as International Law on the Rights of Women. In its article 30, the Convention explicitly defines discrimination against women and sets an agenda for national action to end such discrimination. Convention targets culture and tradition as influential forces shaping gender roles and family relations, and is the first treaty of human rights which affirms the reproductive rights of women (http://www.un.org/en/globalissues (women/).

In 1985, a conference was held in Nairobi World Review and Appraise the Achievements of the United Nations Decade for Women: Equality, Development and Peace. This conference was held at a time when the movement for gender equality had finally gained global recognition and 15,000 NGO representatives participated in a parallel forum of NGOs. This point many describe as "the birth of global feminism." Seeing that the goals of the Conference in Mexico City were not adequately managed, 157 participating governments adopted the Nairobi Progressive Strategies to 2000. An early result of the Nairobi conference was voluntary transformation Fund "Decade of Women" at the UN "Development Fund for Women," UN (UNIFEM), now part of UN Women (http://www.un.org/en/globalissues/women/).

\subsection{UN's role in preventing and combating family violence}

Organization of the United Nations as the largest organizations and most influential global world increasingly is putting the issue of family violence in the spotlight her, discussing the problem, defining tasks and recommendations to the member states and organizing various campaigns.

International Bill of Human Rights consists of the Universal Declaration of Human Rights, adopted by the General Assembly of the United Nations in 1948, and its implementing conventions, the International Covenant on Civil and Political Rights (ICCPR) and the Convention international Covenant on Economic, Social and cultural rights (ICESCR), which entered into force in 1976. While these documents do not explicitly address family violence, they, along with the Optional Protocol to the ICCPR, articulate the duty of the state to protect the basic human rights that are violated commonly in cases of family violence. These rights include the right to life, the right to physical and mental integrity, the right to equal protection before the law and the right to be free from discrimination (http://www1.umn.edu/humanrts/svaw 
/domestic/laws/international.htm\#un).

Besides Conventions, important role for UN work in the field of family violence and protect its victims have the documents of international conferences of the UN to address the issue of women and family violence. These documents are known as a consensus document on the state of international law.

Report of the World Conference of the United Nations Decade for Women: Equality, Development and Peace, held in Copenhagen in 1980, was the first document in which family violence was clearly mentioned in an official document of the United Nations. Family violence is sometimes referred to in this document. Here note:

- The legislation must also be approved and implemented in order to prevent family violence and sexual violence against women.

- Must take all appropriate measures, including legislative ones, to allow victims to be treated fairly in all criminal proceedings (SVAW (Stop Violence against women), http://www1.umn.edu/humanrts/svaw/domestic/laws linternational.htm\#un).

In the Third World Conference on Women (1985) in Nairobi, Kenya, family violence received considerable attention. The final report of the conference urged governments to "take effective measures, including mobilizing community resources to identify, prevent and eliminate all forms of violence, including family violence against women and to provide housing, reorientation and support services for abused women and children (SVAW (Stop Violence against women), http://www1.umn.edu/humanrts/svaw/domestic/laws/international.htm\#un).

The final document of the Second World Conference on Human Rights held in Vienna in June 1993, was the Vienna Declaration and Programme of Action, which states: "In particular, the World Conference on Human Rights stresses the importance of working towards the elimination of violence against women in public and private life,.... elimination of gender bias in the administration of justice and the eradication of any conflicts which may arise between the rights of women and the harmful effects of certain traditional or customary practices" (Vienna Declaration and program of action, the World Conference on Human Rights, Vienna, June 14 to 25, 1993, A/CONF.157/23, July 12, 1993).

Violence against women, including family violence, had a particular focus on the Fourth World Conference on Women in Beijing, China (1995). The conference document, the Beijing Platform for Action identifies family violence as a violation of human rights. The platform states: "Violence against women violates the limit or not allow women the enjoyment of their human rights and fundamental freedoms". It addresses violence against women as a "critical area of concern" specific and includes it in the "human rights". Beijing Platform of many highlights concrete actions that governments should undertake, nongovernmental groups and others to confront and combat violence against women, including strengthening the legal response to family violence. Five years later, the United Nations Conference, Beijing plus 5, at the special session on Women 2000: Gender Equality, Development and Peace for the twenty-first century, the document stressed thoroughly swept obstacles for women and family violence here (SVAW(Stop Violence against women), http://www1.umn.edu/humanrts/svaw/domestic/laws/international.htm\#un).

Other documents of the United Nations conference to address the issue of Family Violence:

- Programme of Action of the International Conference on Population and Development (ICPD) in Cairo, Egypt (1994), articulates the need for government ATTENTION to all forms of violence against women. Was this need highlighted and again in the document "Cairo plus 5"

- Programme of Action of the Second International Conference on Population and Development (ICPD) in 1999.

- Copenhagen Declaration on Social Development at the World Summit for Social Development in Copenhagen in 1995 also calls on governments to take effective Measures to combat and eliminate all forms of violence against women.

- The Durban Declaration and Programme of Action of the World Conference against Racism, racial discrimination, xenophobia and Related Intolerance Held in this Regard in 2001 in Durban, Admits intersection of gender and race, Ethnicity or status Can Make Any other particularly women Exposed to Certain KINDS of violence and calls on governments " to Consider the Adoption and Implementation of immigration policies and Programs That Would Enable Immigrants, women and children in Particular Who are Victims of spousal abuse or violence, abusive relationships to free themselves" (SVAW(Stop Violence against women), http://www1.umn.edu/humanrts/svaw/domestic/laws/international.htm\#un).

\subsection{Convention on the Elimination of All Forms of Discrimination against Women}

On 18 December 1979, General Assembly of UN Adopted Convention on elimination of All Forms of Discrimination against Women. It entered into force or an international Agreement on September 3, 1981 after being ratified by twenty 
Countries. By the TENTH anniversary of the Convention in 1989, nearly one hundred Countries Agreed to take the Obligations of Its Provisions. The Convention Was the culmination of more than thirty years of work of the United Nations Commission on the Status of Women, a body established in 1946 that was to monitor the Situation of Women and promote their rights. Was the Commission's work to bring to light all the Areas in which women are denied Equality with men? These Efforts for the Advancement of women have resulted in Several Declarations and conventions, of which the Convention on the elimination of All Forms of Discrimination against Women of FOREMOST and is the most comprehensive document (http://www.stopvaw.org/UN_Treaties_and Conventions.html).

In its Preamble, the Convention explicitly notes that "extensive discrimination against women continues to exist ", and emphasizes that such discrimination "violates the principles of equality of rights and respect for human dignity". As defined in article 1, discrimination is understood as any distinction, exclusion or restriction made on the basis of sex... in the political, economic, social, cultural, civil or any other field". Convention gives positive affirmation principles of equality by requiring Member States to take "all necessary measures, including legislative ones, to ensure the full development and advancement of women, in order to guarantee them the exercise and enjoyment of human rights and fundamental freedoms on a basis of equality with men." The political significance of this Convention strengthened by the adoption of the Optional Protocol to the Convention on the Elimination of All Forms of Discrimination against Women and the General Recommendation 19 of the Committee of the Convention (Recommendation 19, the Committee on the Elimination of Discrimination against Women, Violence against women (Eleventh session, 1992), UN Doc. A/47/38 at 1 (1993)).

The Optional Protocol provides international remedies and women the opportunity to gain justice in particular cases and to achieve greater effect by pushing governments to take action at the national level inalienable. Meanwhile, General Recommendation 19 strengthens the Convention on the Elimination of all forms of discrimination against women, particularly in the area of family violence. In it, clearly indicate that family violence is included in the Convention, although not explicitly mentioned. This recommendation requires signatory states to take all necessary measures to overcome violence: they should include the adoption of specific legislation on family violence, including criminal provisions and remedies. Recommendation also states that gender based violence is a "form of discrimination that seriously inhibits women's ability to enjoy rights and freedoms on a basis of equality with men." This was the first recommendation of the agreements or treaties of human rights that officially prohibits violence against women.

\subsection{Declaration on the Elimination of Violence against Women}

In 1993, the General Assembly of the United Nations adopted the Declaration on the Elimination of Violence against Women (DEVAW). This historic document is the result of efforts within the United Nations Commission on the Status of Women (CSW) and the Economic and Social Council (ECOSOC). While DEVAW no binding legal authority of a convention or treaty, as a statement of the General Assembly of the UN, is universal in terms of involvement and a strong statement of the principle of the international community.

To identify the dependence of women as the main cause of family violence, DEVAW states: "Violence against women is a manifestation of historically unequal power relationships between men and women, which have led to domination over and discrimination against women by men". DEVAW condemns crucial social mechanisms by which women are forced into a lower position compared with men " and defines violence as something that happens both in private and in public that". Most importantly DEVAW provides specific steps that member states should take to combat family violence, including reform of the legal system. DEVAW provides that states must investigate and punish acts of violence, to develop programs to full legal, political, administrative and cultural to prevent violence against women, provide training for law enforcement officials, to promote training and research collection of data about the prevalence of family violence (Declaration on the Elimination of Violence against Women, UN Doc. A/48/49 (1993), which can be obtained at: http://www1.umn.edu/humanrts/instree/e4devw.htm).

\subsection{UN Women}

On 2 July 2010, the General Assembly of the United Nations voted unanimously to create a single body within the UN charged with accelerating progress in achieving gender equality and women's empowerment. The new unit of the UN Gender Equality and the Empowerment of Women, or UN Women merged the four global agencies and offices: Development Fund for UN Women (UNIFEM), the Department for the advancement of Women (DAW), the Office of Counsel special gender and International Institute for research and Training UN to advance women (UN-INSTRAW). The creation of UN Women came about as part of the reform agenda of the United Nations, bringing together resources and 
mandates for greater impact. It joins and builds on the important work of four previously separate parts of the UN system, which focused exclusively on gender equality and women's empowerment (http://www.un.org/en/globalissues/women/).

On 14 September 2010, UN Secretary - General Ban Ki -moon announced the appointment of Michelle Bachelet, former president of which, as Undersecretary General for UN Women. UN Women was put into operation on 1 January 2011. UN member states undertook an historic step in accelerating the organization's goals on gender equality and women's empowerment.

The main roles of UN Women are:

- To support inter-governmental bodies, such as the Commission on the Status of Women, in their formulation of policies, global standards and norms.

- To assist member states in implementing these standards, standing in readiness to provide adequate technical support and financial as well as financial support to those countries that request it, and to establish effective partnerships with civil society.

- Maintain entire UN system responsible (accountable) for their commitments on gender equality, including regular monitoring of progress (http://www.un.org/en/globalissues/women/).

International agreements that guide the work of UN Women are:

- Convention on the Elimination of All Forms of Discrimination against Women (CEDAW).

- Beijing Declaration and Platform for Action (PFA).

- Resolution 1325 of the Security Council of the UN on women, peace and security (2000) which recognized that war affects women differently, and reaffirmed the need to enhance the role of women in decision making in the field of conflict prevention and resolution of their. The Security Council of the UN, following four resolutions adopted subsequent to women, peace and security: 1,820 (in 2008), 1,888 (in 2009), 1,889 (in 2009) and 1,960 (in 2010). Taken together, the five resolutions represent a critical framework for improving the situation of women in countries affected by conflict.

- Millennium Declaration and Millennium Development Goals (http://www.unwomen.org/about-us/guidingdocuments/).

\subsection{UNiTE campaign of Secretary General of the UN Ban Ki-Moon}

The campaign of Secretary General of the UN, Ban Ki - Moon "Join to End Violence against Women (UNiTE to End Violence Against Women) " is aimed at preventing and eliminating violence against women and girls in all parts of world. UNiTE brings together a range of agencies and offices of the UN to promote action across the UN system to prevent and punish violence against women.

Through UNiTE, the UN joins forces with individuals, civil societies and governments to end all forms of violence against women. UNITE was launched in 2008 as a campaign of Secretary General Ban Ki - Moon, who has been a multiyear effort to prevent and eliminate violence against women and girls in all parts of the world. UNiTE calls on governments, civil society, women's organizations, youth, private sector, media and the entire UN system, to join forces in addressing the global pandemic of violence against women and girls (http://endviolence.un.org/about.shtml).

UNiTE aims by 2015 to achieve five goals in all states:

- The adoption and implementation of national laws to address and punish all forms of violence against women and girls;

- Adoption and implementation of multi-sectorial action plans at the national level;

- Consolidation and strengthening of collecting important data on violence against women and girls;

- Raising public awareness and social mobilization and

- Addressing sexual violence in conflict (http://endviolence.un.org/about.shtml).

\section{The Role of the Council of Europe for the Prevention and Suppression of Family Violence}

The system of human rights in the Council of Europe is made up of agreements, which regulate the obligations of member states and non-binding documents such as guidelines, recommendations and resolutions. Council of Europe is very active in the field of family violence and protects victims of family violence. EC's work on the issue of family violence has begun to Recommendation No. R (85) 4, which was approved by the Committee of Ministers in 1985. This recommendation was followed by Recommendation No. R (90) 2 on social measures and family violence. Violence against women, including family violence, was also the theme of the Conference of the Third, Fourth and Fifth European 
Ministers (SVAW(Stop Violence against women), http://www1.umn.edu/humanrts/svaw/domestic/laws Iregional.htm\#COE).

The theme of the Third Conference in Rome in 1993 was "Strategies for the elimination of violence against women in society: the media and other means." At the conclusion of this conference, the Ministers adopted a declaration recommending that the draft EC and action plan to condemn violence against women (SVAW(Stop Violence against women), http://www1.umn.edu/humanrts/svaw/domestic/laws/regional.htm\#COE).

Fourth European Conference of Ministers for equality between women and men in Istanbul in 1997 was drafted "Declaration on equality between women and men as a fundamental criterion of democracy". In this document, the EC invited ministers to prepare an instrument that determines the position of CEO for family violence and recommends that member states work to reduce male violence "by initiating education to ensure respect for the other person and how respect to violent men, by supporting practical initiatives and therapeutic" (SVAW(Stop Violence against women), http://www1.umn.edu/humanrts/svaw/domestic/laws/regional.htm\#COE).

Fifth European Conference of Ministers for equality between women and men, held in Skopje on 22 and 23 January 2003, the European Council adopted the report "Gender Equality: The main issue in changing societies", a document which was sent to recommendations by the Committee of Ministers preparatory Committee for equality between men and women in relation to violence against women. As part of these recommendations was emphasized the need "to raise awareness of the abuse of human rights during and after conflict and the frequency of family violence.

Was finalized in 1998 "Action Plan to condemn violence against women", describing Specialist Group knowledge regarding the nature of violence against women, the purpose of this problem, the work being undertaken and the challenges and current problems. The report also describes the Action Plan for the EC member states. Action Plan recommends a number of strategies to condemn family violence, including the implementation of legislative reforms. The plan also emphasizes the importance of prevention, education, victim assistance and treatment of offenders (SVAW(Stop Violence against women), http://www1.umn.edu/humanrts/svaw/domestic/laws/regional.htm\#COE).

Recommendation No. R (2002) 5 "Protecting women against violence", was adopted by the Committee of Ministers on 30 April 2002. In this resolution, the Committee "reaffirmed that violence against women is a result of unbalanced power relations between men and women and leads to discrimination are serious feminine within society and within the family "and" affirmed that violence against women violates and impairs or not allows them the enjoyment of their human rights and fundamental freedoms ". This recommendation urges member states to:

- Review their legislation and policy from the standpoint of ensuring the fulfillment of women's rights;

- To recognize that states have an obligation to exercise due diligence to prevent, investigate and punish acts of violence, no matter that these acts are perpetrated by the state or individuals, and to provide protection to victims;

- Acknowledge that male violence against women is a major problem and social structural based on unequal power relations between women and men and therefore men encourage active participants in actions aimed at combating violence against women ;

- Encourage all relevant institutions dealing with the issue of family violence (police, social and medical professionals) to develop medium and long term action plans that enable activities to prevent violence and protect victims;

- Promote research, data collection and collaboration in national and international level;

- To promote the creation of programs in higher education and research centers including university level, dealing with the issue of equality, particularly violence against women;

- To improve the interaction between the scientific community, NGOs in the field, policy making and legislative institutions, health, education, social and police, with the aim of developing coordinated actions against violence;

- Adoption and implementation of the measures described in the appendix to this recommendation in the manner they consider most appropriate under the circumstances and national preferences and for this purpose, to consider drafting a national action plan to combat violence against women (SVAW(Stop Violence against women), http://www1.umn.edu/humanrts/svaw/domestic/laws/regional.htm\#COE).

In April 2000, the Parliamentary Assembly of the Council of Europe adopted Recommendation 1450 on violence against women in Europe. In this recommendation, the Parliamentary Assembly urged the Committee of Ministers to establish a European program to combat violence against women, noting that notes that "despite the fact that family violence is one of the most common forms of violence against women, however observed at least. It is estimated that in terms of today more and more women are dying or are seriously injured by family violence each year, more than cases 
that die from cancer or traffic accidents". It also requires that "the approved provisions that would prohibit all forms of family violence, family legal recognition of her marriage and incrimination, providing greater protection for women, as for example by means of access ban the violent spouse in marital and common house tools for successful realization of imprisonment, and enabling greater flexibility in relation to access to justice and access to various procedures, with provision for the procedure ex officio by the authorities in video hearings and equal representation of male and female judges".

\subsection{Convention on preventing and combating violence against women and family violence (CAHVIO)}

In 2008, by decision of the Committee of Ministers is formed multidisciplinary Ad Hoc Committee on preventing and combating violence against women and family violence (CAHVIO) with a mandate to prepare a binding legal standards in two areas: 1. Preventing and combating family violence, including specific forms of violence against women and other forms of violence against women and 2. Protect and support the victims of this violence and prosecution of the perpetrators of this violence (http://www.coe.int/t/dghl/standardsetting/convention-violence/about_en.asp).

Convention on preventing and combating violence against women and family violence was adopted by the Committee of Ministers of the Council of Europe on 7 April 2011. Opened for signature on 11 May 2011 on the occasion of the 121th session of the Committee of Ministers in Istanbul. It came into force after the ratification of 10 member countries. On 8 July 2011, the Republic of Macedonia became the 15th member of the Council of Europe which signed the Convention. This historic new treaty is the first legally binding instrument in the world creating a comprehensive legal framework to protect women from all forms of violence. For the first time in Europe, was brought CAHVIO Convention binding legal standards for the prevention of violence against women, including family violence, protecting victims and punishing perpetrators. The Convention covers a large gap to women's human rights and also extends protection to all victims of family violence. By ratifying the Convention, states are obliged to implement the provisions extremely detailed and precise obligation which creates positive action in the state. The Convention does not create new rights, but clarifies existing human rights and creates a positive obligation on signatory states to promote, to prevent violations of human rights and to protect victims (Analysis of national legislation and the identification of core areas that should fit with the provisions of the Council of Europe Convention on preventing and combating violence against women and domestic violence - CAHVIO, Author: Stoyanka Mircev, 2011).

In the second chapter of this Convention contained provisions for integrated policies, while the third chapter and the fourth related provisions for prevention and for protection and support. Provisions of substantive law contained in the Fifth Chapter of the Convention and represent the core of the Convention. As a consequence of the principle of integrated policies adopted, provisions in the field of civil, administrative and criminal are located in a section, respectively emphasized that efficient and effective prevention and combating family species included in the Convention require coordination and amendments to the laws governing mutual various fields. In the sixth chapter of the Convention contained provisions dealing with procedural law. Particular attention is paid to the investigation, prosecution and protection measures (Analysis of national legislation and the identification of core areas that should fit with the provisions of the Council of Europe Convention on preventing and combating violence against women and domestic violence CAHVIO, Author: Stoyanka Mircev, 2011).

\subsection{European Union's role in the prevention and suppression of domestic violence}

European Union legislation has few laws that deal specifically with domestic violence. However, the obligations imposed by the legal framework of the EU in relation to violence against women orients the obligations of Member States regarding family violence. Although not legally binding, the resolution issued by the European Parliament to show that criminal incrimination of family violence is an appropriate way for states to meet their legal obligations under EU law. In its resolution on the report of the Commission to the Council, the European Economic and Social Committee and the Committee of the Regions on the state of women's health in the European Community, the European Parliament called on member states to "criminalize family violence against women, including rape within marriage and sexual mutilation, and providing services to help women who are victims of this type of violence" ((COM (97) 0224 C4-0333/97), Gazeta Zyrtare C175, 21 qershor 1999, http://www1.umn.edu/humanrts/svaw/domestic/laws/regional.htm).

The European Parliament and the European Council in 2001 proposed a new directive that will enable victims of domestic violence, the ability to maintain the right of residence (citizenship) in the EU (the EU country) after divorcing husband there is a resident (citizen) of the EU. Article 13 (2) of the proposal to the European Parliament and Council 
Directive on the right of Union citizens and their families to move freely within the territory of member states, provides that "divorce or annulment of marriage shall not entail the loss of the right of residence of family members of an EU citizen who are not nationals of a Member State when... (c) This is warranted by particularly difficult circumstances". Accompanying Explanatory Memorandum explains that "the wording in this section is unclear and is intended to supplement, especially in situations of family violence." Later, in 2002, Opinion Economic and Social Committee on the " Proposal for European Parliament and Council Directive on the right of Union citizens and their families to move and reside freely within the territory of the Member States ", criticizes the wording of Article 13 (2) as unfair and inaccurate and recommended" that the wording... be more explicit, referring to family violence, gender based violence, both forms of violence, and psychological and physical" (COM (2001) 257), Gazeta Zyrtare C149, 21 qershor 2002, http://www1.umn.edu/humanrts/svaw/domestic/laws/regional.htm).

On 8 March 2004, members of the European Parliament called that 2006 be declared as the European Year against violence against women and adopted the first report on family violence in the European Parliament. Pressure from the European Parliament brought the future Constitution of the EU to include the statement according to which the Union "will aim to fight against all forms of violence" and that "Member States shall take all measures necessary to prevent and punish these criminal acts and to provide assistance and protection to victims".

\section{Conclusion}

There is no society who's immune to domestic violence. Domestic violence does no acknowledge boundaries. Since it knows no boundaries, does not know religion or nation, also in the same way it must be fight.

Domestic violence is one of the most serious violations on an individual and is considered the most serious offenses against freedoms and human rights. It is serious violation because the individual is not safe in own family, in its home, in the place where hi is field more comfortable.

But, the problem is there; all state must fight this s.c. phenomenon using all measures.

\section{References}

Beijing Declaration and Platform for Action, Fourth World Conference on Women, Beijing, September 1995 Carolyn Hoyle, Negotiating family Violence: Police, Criminal justice And Victims, Oxford University, 1998 Convention on the Rights of the Child, the General Assembly of UN Resolution 44/25, 20 November 1989 Convention on the elimination of All Forms of Discrimination against Women of the Office of the High Commissioner for Human Rights, September 3, 1981

Council of Europe Convention on preventing and combating violence against women and family violence, April the 12. 2011

Declaration on the elimination of of Violence Against Women, the General Assembly of the United Nations, A/RES/48/104, 20 December 1993

European Commission, Family Violence Against Women Report, Eurobarometer 344, September 2010

Halili, Ragib, "Victimology", 2010, Pristina

Michael S. Kimmel, Male Victims of Domestic Violence: A Substantive and Methodological Research Review, New York, 2001

Michael D. Anestis, Treating female victims of domestic abuse: A test of dialectical behavior therapy, 2009

Minnesota Advocates for Human Rights, Family Violence in Macedonia, 1998

Neerosh Mudaly \& Chris Goddart, The truth is longer than a lie: Children's experiences of abuse and professional intervention, Filadelfi, 2006

The protection of women from violence, Recommendation PRE (2002) 5 of the Committee of Ministers to member states on the protection of women against violence adopted on 30 April 2002 and explanatory memorandum.

Preventing intimate partner and sexual violence against women: taking action and generating evidence, Geneva, World Health Organization, 2010

Recommendation 19, the Committee on the Elimination of Discrimination against Women, Violence against women (Eleventh session, 1992), UN Doc. A/47/38 at 1 (1993)

The Report of the World Conference of the United Nations Decade for Women: Equality, Development and Peace, Copenhagen, July 1980, U.N. Doc A/CONF.94/35 (80.IV.30)

Stojanka Mirceva, Analysis of national legislation and identify basic areas that need to comply with the provisions of the Convention of the Council on preventing and combating violence against women and family violence - CAHVIO, prill 2011

Tamo Karaj,A. Violence against children in Albania, Human Development Centre, the research report funded by UNICEF, Tirana, 2006

UNDP Common action protocol in cases of domestic violence, Skopje, 2010

UNDP, Economic Strengthening women victims of domestic violence - Information Handbook, 2010

Universal Declaration of Human Rights, General Assembly resolution 217 A (III), December the 10, 1948

UNICEF / Human Development Centre, author Adem Tamo \& Karaj, Violence against children in Albania, Tirana, 2006. 
Vienna Declaration and program of action, the World Conference on Human Rights, Vienna, June 14 to 25, 1993, A/CONF.157/23, July 12, 1993

WHO, Violence against woman, November 2009

http://www1.umn.edu/humanrts/svaw/domestic/laws/regional.htm

http://www.coe.int/t/dghl/standardsetting/convention-violence/about_en.asp

http://www1.umn.edu/humanrts/svaw/domestic/laws/regional.htm\#COE

http://endviolence.un.org/about.shtml

www.unwomen.org/about-us/guiding-documents/

http://www.un.org/en/globalissues/women/

http://www1.umn.edu/humanrts/svaw/domestic/laws/international.htm\#un

http://www.oregoncounseling.org/Handouts/DomesticViolenceMen.htm

http://www.unicef.org/protection/index_violence.html 